\title{
Depletion of Gastrin-Releasing Peptide (GRP) from Nerves in the Gastric Body of Rats with Experimental Ulcers. An Immunohistochemical Study
}

\author{
Toshihiko Iwanaga ${ }^{1}$, Qi MeI ${ }^{1}$, Tsuneo FujITA ${ }^{1}$ and Noboru Yanaihara ${ }^{2}$ \\ Department of Anatomy ${ }^{1}$, Niigata University School of Medicine, Niigata, and Laboratory of Bioorganic Chemistry, ${ }^{2}$ University \\ of Shizuoka School of Pharmaceutical Sciences, Shizuoka, Japan
}

Received January 29, 1988

\begin{abstract}
Summary. A predominant population of mucosal nerves in the mammalian gastric body has been known to contain large amounts of gastrin-releasing peptide (GRP). The present immunohistochemical study demonstrates the depletion of GRP immunoreactivity from nerves in the oxyntic mucosa of rats with ulcers induced by restraint plus water immersion. Depletion of GRP occurred in a major part of the nerves after $3 \mathrm{~h}$ exposure to the stress, and after $6 \mathrm{~h}$ exposure only a few nerve fibers could be recognized. In contrast, GRP fibers in the pyloric mucosa did not decrease significantly in number in any of the stressed rats. Since the depletion of GRP immunoreactivity preceded mucosal erosion in the gastric body, the possibility is proposed that GRP released from the nerves may be related to stress-related ulceration in the stomach.
\end{abstract}

Gastrin-releasing peptide (GRP) with 27 amino acid residues was isolated from the non-antral part of the porcine stomach (MCDONALD et al., 1979). The carboxy-terminal region of the peptide was strikingly homologous with bombesin, a peptide with 14 amino acid residues, which was originally isolated from the skin of the frog Bombina bombina (ERSPAMER and MELCHIORRI, 1973). Radioimmunoassay studies revealed large amounts of GRP/bombesin immunoreactivity contained in the oxyntic mucosa of the stomach in mammals (WALSH et al., 1981; YANAIHARA et al., 1981). The immunoreactivity for GRP/bombesin in the pyloric mucosa was one tenth, one fifth and one half as much as that in the oxyntic mucosa in dogs, pigs and rats, respectively (DOCKRAY et al., 1979; WALSH et al., 1981; YANAIHARA et al., 1981). These radioimmunoassay results corresponded to immunohistochemical findings using antisera against GRP or bombesin; namely, immunoreactive nerve fibers were densely distributed in the oxyntic mucosa, but much less numerously in the pyloric mucosa (DOCKRAY et al., 1979; IWANAGA, 1983).

GRP and related peptides have been found to be potent stimulants of gastric acid release in the dog, cat and human (MELCHIORRI, 1978; MCDONALD, 1981). Since enhanced gastric acid output by GRP/bombesin is accompanied by elevated plasma gastrin levels, this effect has been considered to be an indirect action via gastrin released from antral G cells (MELCHIORRI, 1978; WALSH et al., 1981). This idea has been supported by the finding that antrectomy or removal of the antral mucosa greatly inhibits the increase in gastric acid output induced by GRP/bombesin (MELCHIORRI, 1978). However, the concentrated distribution of GRP-immunoreactive nerves in the oxyntic area suggests a possible direct effect of GRP upon the acid-secreting area.

MATSUBAYASH et al. (1982) reported a significant elevation of plasma GRP levels in rats exposed to water immersion stress which induced severe gastric erosion. This finding suggests the possibility that GRP released from gastric nerves might be involved in stress ulceration. The present study deals with an immunohistochemical demonstration of GRP-containing neurons in the gastric mucosa of rats under restraint plus water immersion stress.

\section{MATERIALS AND METHODS}

Adult male Wistar rats (body weight about $200 \mathrm{~g}$ ) were fasted for $24 \mathrm{~h}$ and stressed according to the method by TAKAGI et al. (1964) for producing stress ulcers. Eighteen rats were separated into six groups and exposed to the restraint plus water immersion for $0,3,6,12,18$ and $24 \mathrm{~h}$. Normal and stressed rats were anesthetized by sodium pentobarbiturate ( 40 $\mathrm{mg} / \mathrm{kg}$ body weight) and perfused with a physiologi- 
cal saline through the heart followed by $4 \%$ paraformaldehyde in $0.1 \mathrm{M}$ phosphate buffer, $\mathrm{pH}$ 7.3. The stomach was removed and immersed in the same fixative for an additional $6 \mathrm{~h}$. After fixation, they were rinsed overnight in $30 \%$ sucrose solution at $4{ }^{\circ} \mathrm{C}$ and rapidly frozen in liquid nitrogen. Sections, about $20 \mu \mathrm{m}$ thick, were cut in a cryostat and processed for the peroxidase-antiperoxidase (PAP) method by use of an anti-GRP serum.

The anti-GRP serum, R-6902 was raised in a rabbit by injections of synthetic porcine GRP 1-27 conjugated with bovine serum albumin. The characterization of the antiserum has been described elsewhere (YANAIHARA et al., 1981). The specificity of the immunoreaction was checked by preincubation of the antiserum with synthetic peptide $(10 \mu \mathrm{g} / \mathrm{ml}$ diluted antiserum).

\section{RESULTS}

The perfusion-fixed stomachs of normal and stressed rats were macroscopically compared (Fig. 1). The stomachs of the stressed animals were markedly shrunken as compared with those of the control rats. The longer the exposure to the stress lasted, the more marked was the shrinkage of the organ. Mucosal erosions, small irregular areas blackened by bleeding, were dispersed in the gastric body in all the stressed rats, while no gastric mucosal lesions were present in the control rats. Incidences of hemorrhagic erosions were first recognized in rats stressed for $3 \mathrm{~h}$, but were still small in number and size. They increased in number and size with the time of exposure to the stress. The most severe lesions were observed during 12-24 h of exposure.

Immunostaining by use of the anti-GRP serum showed that the immunoreactivity was localized in the nerves in the rat stomach as reported previously (IWANAGA, 1983). The immunopositive nerves were most densely distributed in the oxyntic mucosa. The nerves took winding courses between the fundic glands and anastomosed into a fine network in the lamina propria (Fig. 2a). Beaded swellings, though not conspicuous, were recognizable through the nerve network. No topographic relationship was found between the GRP fibers and specific cells constituting the fundic glands (Fig. 2b). GRP-immunoreactive nerves were also abundant in the mucosa of the pyloric antrum, in which the nerves gathered around the bottom of the pyloric glands.

In the stressed rats, the GRP-immunoreactive fibers in the oxyntic mucosa conspicuously decreased in number, while those in the antral part did not show any significant decrease. After $3 \mathrm{~h}$ of exposure to the stress, the dense network of GRP fibers disappeared, leaving a small number of rather weakly immunostained, scattered fibers (Fig. 2c). The depletion of GRP-immunoreactivity was seen evenly throughout the oxyntic mucosa. After $6 \mathrm{~h}$ of exposure, the oxyntic mucosa retained only a few nerve fibers with distinct GRP immunoreactivity, whereas the pyloric mucosa and muscle layer revealed many immunoreactive fibers. The immunopositive nerves were rare in the oxyntic mucosa of the animals exposed for $12-28 \mathrm{~h}$ (Fig. 2d).

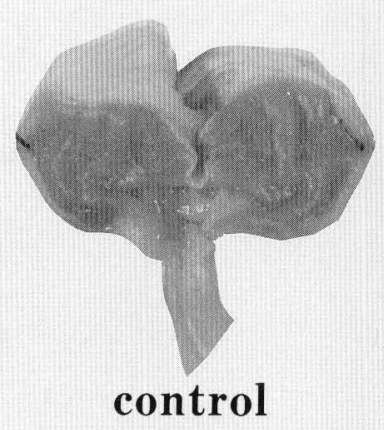

control

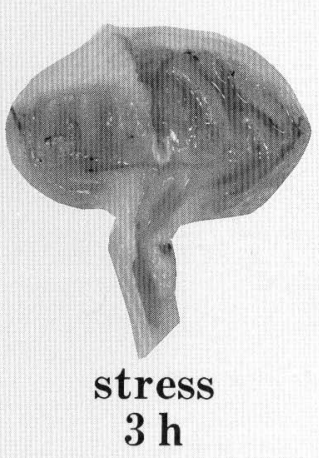

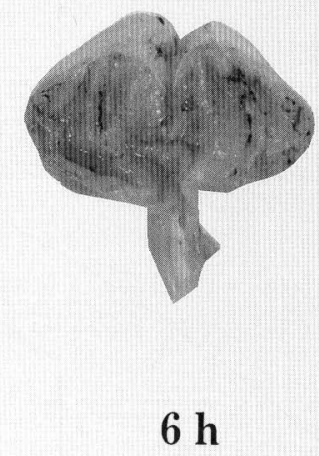

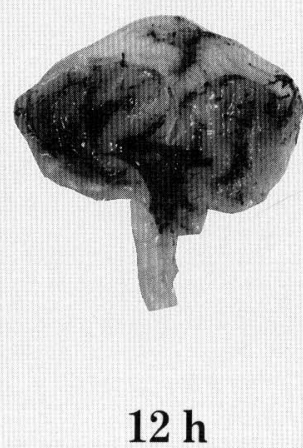

Fig. 1. Macroscopic photograph showing the stomachs of control and stressed rats (3, 6, $12 \mathrm{~h})$. Mucosal erosion is seen as the dot-like or linear areas blackened by bleeding. The stomachs of the stressed animals are considerably shrunken. $\times 1$ 


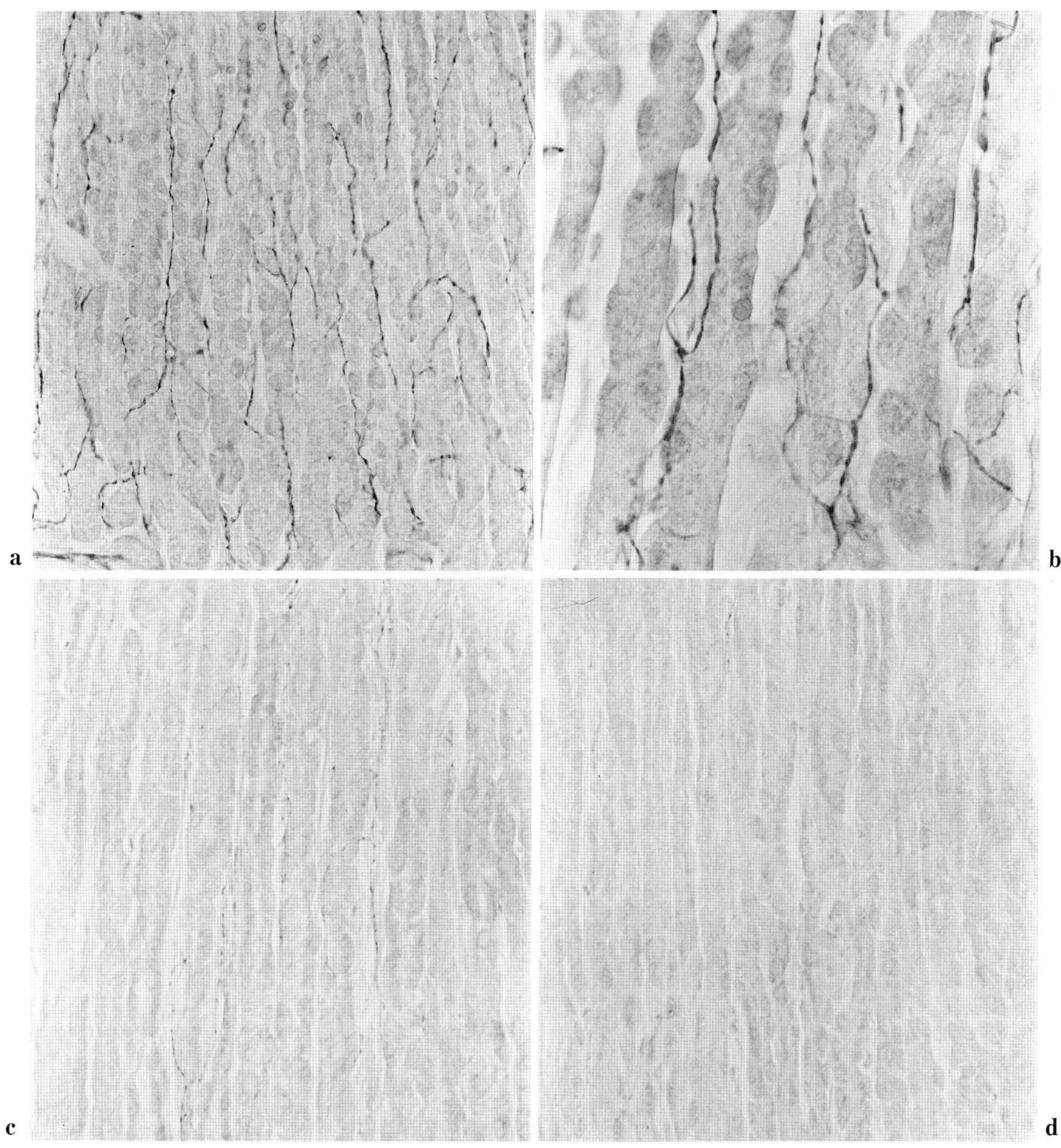

Fig. 2. GRP-immunoreactive nerves in the stomachs of control and stressed rats. PAP staining. In the control rat, numerous immunoreactive nerves are distributed in the lamina propria of oxyntic mucosa (a and b). They conspicu-

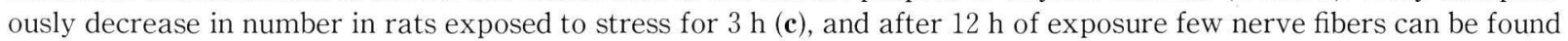
(d). a, c, d: $\times 230 ; \mathrm{b}: \times 400$ 


\section{DISCUSSION}

Previous histological studies have suggested that the GRP-containing nerves might be predominant among nerves supplying the oxyntic mucosa of mammals, including the rat (IWANAGA, 1983; IWANAGA and FuJITA, 1984). Other nerves containing peptides including VIP (vasoactive intestinal polypeptide), NPY (neuropeptide Y) and enkephalins display a minor component in the oxyntic area of the rat (IwANAGA, unpublished data). Considerable numbers of adrenergic fibers have been found in the oxyntic mucosa, but have been restricted to the blood vessels; very few fibers have been recognized between the fundic glands (IwANAGA and FUJITA, 1984). The GRP-immunoreactive nerves in the rat oxyntic mucosa essentially correspond in distribution and number to the nerves demonstrated by cholinesterase staining that likely detects not only cholinergic neurons but also some non-cholinergic neurons (IWANAGA et al., 1984). In other words, the autonomic nerves in the rat oxyntic mucosa are for the most part represented by GRP. immunoreactive fibers. Therefore, GRP-containing neurons are presumed to play an essential, if not exclusive, role in the nervous control of oxyntic mucosa in the rat.

The present study revealed that the depletion of GRP occurred in a major population of nerves after $3 \mathrm{~h}$ of exposure to the stress, and only a few GRPcontaining fibers were present after $6 \mathrm{~h}$. To our knowledge, that a bioactive peptide contained in neurons can be so markedly depleted in such a short time has not been reported. This morphological finding is compatible with the radioimmunoassay results from MATSUBAYASH et al. (1982) on the changes in plasma GRP levels under similar experimental conditions: Plasma GRP levels in rats exposed to the stress for $5 \mathrm{~h}$ were elevated to about 2.5 times the normal levels, thereafter decreasing gradually.

One of the important effects of GRP is the stimulation of gastric acid secretion via gastrin release from pyloric $G$ cells. The present study showed that the depletion of GRP from nerves in the pyloric antrum was not so marked as compared with that in the oxyntic area. In the rat, moreover, it has been claimed that GRP induces gastrin release from antral $G$ cells, though it nevertheless does not eventually influence the release of gastric acid, differing from experimental results obtained using other mammalian species (BERTACCINI et al., 1973; TAKAGI et al., 1986; WALSH, 1987). This has been explained by that GRP might also stimulate the release of some endogenous substances inhibiting the gastric secretion, such as somatostatin (DuVAL et al., 1980). These findings suggest that the release of a large amount of GRP in the oxyntic area might be closely related to the pathogenesis of acute gastric mucosal erosions, although the direct actions of GRP upon the fundic glands remain to be elucidated.

Recent experimental and clinical studies suggest that cases of acute gastric mucosal erosion including the stress ulcers are mainly caused by ischemia in the oxyntic mucosa, but not by excess acid secretion (O'NEILL, 1970; Menguy and Masters, 1974; Kamada et al., 1982). GRP is known to cause smooth muscle contraction and also vasoconstriction (MELCHIORRI, 1978). The possibility, therefore, may exist that GRP contracts the blood vessels supplying the oxyntic mucosa, causing local ischemia. However, this idea raises a problem: the blood vessels in the lamina propria of the oxyntic mucosa densely innervated by GRP are capillaries in nature, lacking any muscles which might respond to GRP (IWANAGA et al., 1987).

Acetylcholine has been suggested to coexist with GRP in nerves in the rat oxyntic mucosa (IwANAGA et a1., 1984). It seems worthwhile to mention here that acetylcholine, however, is not co-released with GRP in rats under the present stress conditions, according to our preliminary observations by cholinesterase histochemistry (to be published elsewhere). This account seems to support the possibility that stress-induced ulceration may be essentially mediated by GRP.

\section{REFERENCES}

Bertaccini, G., V. Erspamer and M. Impicciatore: The actions of bombesin on gastric secretion of the dog and rat. Brit. J. Pharmacol. 49: 437-444 (1973).

Dockray G. J., C. Valllant and J. H. Walsh: The neuronal origin of a bombesin-like immunoreactivity in the rat gastrointestinal tract. Neuroscience 4: 15611568 (1979).

DuVal, J. W., B. Saffouri, G. C. Weir, J. H. Walsh and G. M. MAKhlouf: Release of gastrin and somatostatin by bombesin in the isolated perfused stomach (Abstract). Gastroenterology 78: 1161 (1980).

Erspamer V. and P. Melchiorri: Active polypeptides of the amphibian skin and their synthetic analogues. Pure Appl. Chem. 35: 463-494 (1973).

IwANAGA, T.: Gastrin-releasing peptide (GRP)/bombesinlike immunoreactivity in the neurons and paraneurons of the gut and lung. Biomed. Res. 4: 93-104 (1983).

IwANAGA, T. and T. FuJita: Endocrine cells and neurons 
regulating gastric acid secretion, with special reference to peptide-containing endocrine cells and nerves in the stomach (In Japanease). Peptic Ulcer. 3: 129-139 (1984).

IwANAGA, T., T. FuJita and N. Yanaihara : Occurrence of gastrin-releasing peptide (GRP)-like and vasoactive intestinal polypeptide (VIP)-like immunoreactivities in cholinergic neurons in the digestive tract of the rat. Biomed. Res. 4, Suppl.: 167-172 (1984).

Iwanaga, T., R. Yui, H. Kuramoto and T. Fujita: The paraneuron concept and its implications in neurobiology. In: (ed. by) B. Scharrer, H.-W. KORF and H.-G. HARTWIG: Functional morphology of neuroendocrine systems. Springer, Berlin, 1987 (p. 139-149).

Kamada, T., N. Sato, S. Kawano, H. Fusamoto and H. ABE: Gastric mucosal hemodynamics after thermal or head injury. Gastroenterology 83: 535-540 (1982).

MatsubaYashi, S., M. OoKubo, Y. OOKURA, K. IWAHARa, Y. Yamashita and N. Yanaihara: Gut hormones in rats with experimental ulcer (In Japanese). In: (ed. by) A. Mryoshi, et al.: Proceedings of the gut hormone conference, Vol. 2. Igaku Tosho Shuppan Ltd., Tokyo, 1982 (p. 20-25).

McDonald, T. J.: Non-amphibian bombesin-like peptides. In: (ed. by) S. R. BLOOM and J. M. PolAK : Gut hormones. 2nd. ed. Churchill Livingstone, Edinburgh, 1981 (p. 407-412).

MCDonald, T. J., H. JoRnvall, G. Nilsson, M. Vagne, M. Ghatei, S. R. Bloom and V. Mutt: Characterization of gastrin releasing peptide from porcine non-antral gastric tissue. Biochem. Biophys. Res. Commun. 90: 227233 (1979).

Melchiorri, P.: Bombesin and bombesin-like peptides of amphibian skin. In: (ed. by) S. R. BLOom: Gut hormones. Churchill Livingstone, Edinburgh, 1978 (p. 534540).

Menguy, R. and Y. F. MASters: Mechanism of stress ulcer. II. Differences between the antrum, corpus, and fundus with respect to the effects of complete ischemia on gastric mucosal energy metabolism. Gastroenterology 66: 509-516 (1974).

0'Neill J. A.: The influence of thermal burns on gastric acid secretion. Surgery 67: 267-271 (1970).

Takagi, K., Y. KasuYa and K. Watanabe: Studies on the drugs for peptic ulcer. A reliable method for producing stress ulcer in rats. Chem. Pharm. Bull. 12: 465-472 (1964).

Takagi, A., M. Moriga, H. Narusawa, H. Uchino and M. Aono: Paradoxical effects of gastrin releasing peptide on gastrin release and gastric secretion in the rat. Gastroenterol. Jap. 21: 573-578 (1986).

W ALSH J. H.: Role of gastric bombesin-like peptides and related gene products in gastric secretory function (Abstract). Regul. Peptides 19: 143 (1987).

W ALSH, J. H., J. R. ReEve, Jr. and S. R. Vigna: Distribution and molecular forms of mammalian bombesin. In: (ed. by) S. R. Bloom, and J. M. PolAK,: Gut hormones. 2 nd. ed. Churchill Livingstone, Edinburgh, 1981 (p. 413418).

Yanaihara, N., Ch. Yanaihara, T. Mochizuki, K. Iwa HARA, T. FuJITA and T. IWANAGA: Immunoreactive GRP. Peptides 2 (Suppl. 2): 185-191 (1981).

Dr. Toshihiko IwANAGA
Department of Anatomy
Niigata University School of Medicine
Asahimachi, Niigata
951 Japan
岩 永 敏彦
951 新潟市旭町通 1
新潟大学医学部
第三解剖学教室

